\title{
Breeding Sorghum Using Induced Mutations: Future Prospect for Namibia
}

\author{
Maliata Athon Wanga ${ }^{1,2 *}$, A. Ashok Kumar ${ }^{3}$, Grace Nandesora Kangueehi' ${ }^{2}$, Hussein Shimelis ${ }^{4}$, \\ Lydia N. Horn', Fatma Sarsu' ${ }^{6}$, Jahanna F. N. Andowa1
}

${ }^{1}$ Directorate of Research and Training, Ministry of Agriculture, Water and Forestry, Windhoek, Namibia

${ }^{2}$ Department of Agriculture and Natural Resources Sciences, Namibia University of Science and Technology,

Windhoek, Namibia

${ }^{3}$ International Crops Research Institute for the Semi-Arid Tropics (ICRISAT), Hyderabad, India

${ }^{4}$ School of Agriculture, Earth and Environmental Sciences, University of KwaZulu-Natal,

Pietermaritzburg, South Africa

${ }^{5}$ Multidisciplinary Research Centre, University of Namibia, Windhoek, Namibia

${ }^{6}$ Plant Breeding and Genetics Section, Department of Nuclear Sciences and Applications, International Atomic Energy Agency

(IAEA), Vienna International Centre, Vienna, Austria

Email: *maawanga@gmail.com

How to cite this paper: Wanga, M.A., Kumar, A.A., Kangueehi, G.N., Shimelis, H., Horn, L.N., Sarsu, F. and Andowa, J.F.N. (2018) Breeding Sorghum Using Induced Mutations: Future Prospect for Namibia. American Journal of Plant Sciences, 9, 2696-2707.

https://doi.org/10.4236/ajps.2018.913196

Received: November 1, 2018

Accepted: December 21, 2018

Published: December 24, 2018

Copyright (c) 2018 by authors and Scientific Research Publishing Inc. This work is licensed under the Creative Commons Attribution International License (CC BY 4.0).

http://creativecommons.org/licenses/by/4.0/

\begin{abstract}
In arid and semi-arid regions of the world sorghum stands out as a climate change-ready crop with high potential for the production of food, feed, fodder, fiber and fuel in the face of increasing human population. The present review highlights induced mutation breeding technique as a potential tool for improving sorghum in Namibia. The review discussed the following issues; crop improvement using mutagens, mutant screening, selection and evaluation, impact of induced mutation breeding, factors for declining production and future implication of sorghum mutation breeding. In Namibia, severe drought stress resulting in total crop failure has become frequent. This is partly a consequence of farmers growing crop varieties which cannot withstand impact of drought. As such Namibia has limited drought tolerant varieties available for the diverse agro-ecologies. Farmers keep growing the familiar landraces which performs well in good rainfall years but fails to produce stable yield with irregular and erratic rainfall. Thus, breeding new sorghum varieties of high yield and quality combined with multiple agronomic traits including pest and disease resistance and high efficiency in nutrient and water use is needed. Induced mutation is one of the breeding methods utilized worldwide to supplement conventional breeding for developing superior varieties with desirable traits in different crops. Development of high yielding, drought tolerant, and dwarf sorghums with early maturity enables effective utilization of available soils moisture and in optimizing plant density for
\end{abstract}


achieving higher yield in farmers' fields. Recombination breeding through exploitation of natural genetic variability and mutation breeding to reduce the plant height without disturbing agronomic superiority of elite lines is recommended for sorghum improvement in Namibia.

\section{Keywords}

Breeding, Induced Mutation, Namibia, Sorghum

\section{Introduction}

Sorghum [Sorghum bicolor (L) Moench, $2 \mathrm{n}=20$ ] is the fifth-highest produced cereal crop after maize, wheat, rice and barley in the world. In Namibia, sorghum is the third most grown crop after pearl millet and maize [1]. However, maize is cultivated on a large scale under irrigation while sorghum and pearl millet are entirely grown under dry land [2] [3]. This makes sorghum the second crop cultivated under rain-fed agriculture after pearl millet. Given aridity condition of Namibia, sorghum is cultivated primarily for its drought tolerance with lower water requirements than most cereal crops [4] [5]. In the poorest and food-insecure semi-arid region of the developing world, sorghum is mainly grown for food and fodder [6] [7]. Sorghum has high potential for food, feed, fodder, fiber and fuel production in water scarce and low input agriculture with its adaptation to diverse agro-climatic conditions.

In Namibia, sorghum has been under cultivation well before the Europeans engaged in African exploration particularly for food [8]. The records reveal that sorghum was long cultivated in most part of the country including the north central (Ondonga), far northeast (Andara and Linyanti) and the central region (Omaruru) as of 1800s [8]. However, sorghum production to date is predominantly a minor crop of interest that is left to subsistence farmers [3] [9]. Due to the climate variability and change, there is a need to enhance sorghum productivity for improved sustainable food production and income generation, especially for resource poor farmers. This demand for a better understanding of limitations, improvement needed in sorghum-value-chain and policies for an effectively sorghum-based economy [10]. At the same time, improved varieties and effective coordination of the entire breeding process and activities of generating cultivars and their release, seed production and distribution need to be well-organized and regulated.

Breeding efforts of sorghum in Namibia has a short relatively history that can be traced to the 1990s which led to the release of two sorghum varieties, namely Macia (SDS 3220) developed by the then Ministry of Agriculture and Rural Development in collaboration with the International Crop Research Institute for the Semi-Arid Tropics (ICRISAT) and Red sorghum selected from local landraces [11]. Macia is a high yielding, semi-dwarf and early maturing variety and Red sorghum is a tall and late maturing variety [12]. These are the only two va- 
rieties officially released and commonly used in the country. The adoption rate of Macia and Red sorghum by smallholder farmers and their impact on sorghum production at the national level is not well-documented [3]. Majority of smallholder farmers select and grow varying landrace sorghum cultivars which are not well characterized for utilization [3] [13]. Another breeding effort started in 2007 through induced mutation breeding program which involved exposing seed to gamma rays to develop new varieties [14] [15]. Mutation breeding was initiates to generate high yielding, drought tolerant and dwarf sorghums with early maturity to enable effective utilization of available soils moisture and optimizing plant density for achieving higher yield in farmers' fields. In 2017, four promising mutant lines of high yield were pre-released and eight advanced mutant lines were listed [14] [16]. These varieties are being multiplied at the Government Research Stations for distribution to the sorghum growing areas. The successful use of induced mutation breeding technique has proven to be an effective tool to improve locally adapted and well-characterized cultivars. Induced mutation breeding stands out as a prospective tool to speed up the development of improved varieties required for enhanced sorghum production in Namibia. This review highlight induced mutation breeding technique methods as a potential tool for improving sorghum in Namibia, discussing the following issues: crop improvement using mutagens, mutant screening, selection and evaluation, impact of induced mutation breeding, factors for declining production and future implication of sorghum mutation breeding in Namibia.

\section{Literature Review}

\subsection{Crop Improvement}

Plant breeding is a technology based on the art and science of changing the characteristics of plants to develop desired traits. Crop breeding can be traced to its early domestication when people selected individual plants for cultivation. For sorghum, it is assumed that the first mass selection of improved sorghum plants was in Africa [17] [18]. It is presumed that the first selected plants had novel genes that resulted from spontaneous mutations, the only source of selection of plants suitable for domestication at that time [19] [20] [21]. Since sorghum has up to $15 \%$ outcrossing, the cultivated species could have continued crossing with wild species, allowing considerable gene flow from wild species to cultivated species [18] [22]. As the cultivated area expanded, the gene flow from wild species could have been stopped resulting in polymorphic populations [22]. It is likely that farmers continued with the selection and maintenance of best plants, creating the current sorghum races viz., bicolor, caudatum, durra, guinea and kafir [22].

After the discovery of the principles of heredity and the concept of genes in the 1800s and 1900s, plant genetics became essential in crop breeding programs [20] [23] [24]. This advancement in breeding tools has increased the efficiency of breeding including induced mutation which involves exposing plant materials 
to mutagens [20] [23] [25]. Sorghum breeders' interest in utilizing induced mutation is to create genetic variability in plant population to meet the need of yield, quality, resistance and environmental adaptation [26]. However, the successfulness of utilizing induced mutation depends mainly on a well-defined objective for improvement [25]. According to [26] induced mutation is commonly utilizing to: 1) improve specific traits in a preferred cultivar, 2) induce a morphological marker in a promising line for variety registration and 3) induce male sterility or fertility restoration for hybrid variety. Thus, the first step for sorghum mutation breeding in Namibia is to identify specific limitation such as susceptible to pest, diseases, shattering and lodging in the farmers preferred cultivars in which mutation is to be induced.

\subsection{Mutagen and Dose Treatment}

After the trait to be induced has been determined the next step is mutagenesis. In sorghum, the effect of single treatment and combination of physical and chemical mutagens on germination, survival, seedling growth, seedling fertility variation and chlophyll mutation frequency in $\mathrm{M} 1$ and $\mathrm{M} 2$ has been utilized to determine the dose treatment [27] [28] [29]. The doses that causes between 30 to $50 \%$ reduction in germination, survival and seedling growth in selected [30] [31]. Mutagenic effectiveness has been found to be greater at doses between 300 and 500 gy x-rays and gamma and $0.1 \%$ and $0.3 \%$ ethyl methane sulphonate (EMS) [28] [32] [33]. 100 gy gamma ray, 0.1\% EMS and 100 gy $+0.1 \%$ EMS were found to be most effective treatments on growth and yield components [29] [34]. In Namibia, gamma irradiation was the only mutagen used in sorghum induced mutation breeding. The radio-sensitivity on the materials used was determined at FAO/IAEA laboratory in Vienna, Australia. Therefore, Namibia needs to determine dose treatments of gamma for its breeding program. Given limited facilities of gamma irradiation in Namibia and the low cost involved in utilizing EMS mutagen, research is should be extended to determining the effectiveness use of EMS and gamma radiation on Namibian sorghum varieties.

\subsection{Mutant Selection and Evaluation}

Mutant screening and selection techniques are divided in three main type viz., physical or mechanical; visual or phenotypic; "other" methods [26] [34]. In physical and visual screening, suitable traits such as color, size, weight, plant height, growing period, disease resistance, lodging resistance and shattering are utilized [30] [35] [36]. In "other" selection techniques physiological, biochemical, and physio-chemical procedures are utilized [36]. The commonly selection of mutant process is based on phenotype [20] [26]. After the successful identification and selection of the mutants in M1 to M3, in M4 to M7, the mutant is compared with the mother variety and other cultivated varieties in the same procedure as other newly developed varieties [26] [29]. The mutant is studied for combination ability to produce agronomic traits for a wide range of agro-ecologies and multi-location yield evaluation. 


\subsection{Impact of Induced Mutation Breeding in Sorghum}

Research related to the utilization of induced mutation breeding in sorghum is limited. This is attributed to the large number of natural genetic variation of sorghum [34]. According to [6] over 36,700 sorghum germplasm were maintained at International Crops Research Institute for the Semi-Arid Tropics (ICRISAT), India, the number now stands at $>40,000$; about 8000 in Ethiopian; $>42,200$ at the National Plant Gerplasm System (NPGS), USA; >12,800 at National Genetic Germplasm Resources Bank, China. In Namibia, about 180 germplasm were collected from farmers [11]. The diversity of these genetic resources is not fully exploited in terms of characterization, evaluation and documentation for utilization [23] [24]. Another reason could be the low number of researchers working on sorghum breeding [37]. According to literature only two researchers are working on sorghum breeding program in Namibia compared with China (200), India (150), Ethiopia (50) and Sudan (21) [11]. Although the utilization of induced mutation has been limited in sorghum, it is an important tool in breeding superior varieties of desirable traits of different crops species. Over 3,200 mutants of major cereal crops have been listed on the data base of [16]. Most mutants are of rice (821), barley (309), wheat (289) and maize (96) (Table 1). Given sorghum as the fifth highest produced crop in the world, only 15 mutant varieties released in China (5), India (1), Indonesia (1) and Mali (8) reflects limited interest and documentation in induced mutation breeding in sorghum (Table 1). At ICRISAT, induced mutagenesis helped in reducing the height of biofortified sorghum cultivar ICSV 15013 which is currently under multi-location testing under the All India Coordinated Sorghum Improvement Program towards its release.

The database show that mutants developed in different parts on the world were for multiple traits, high grain and fodder, semi-dwarf, synchronous maturity, more sugar content, resistance to lodging, resistant to drought, resistant to diseases and insect pest, grain quality (zinc, iron, protein, tannin, and starch) and for machine harvestibility (Table 2). In Indonesia, irradiation with gamma and ion-beams were utilized to generate sorghum varieties of high yield, quality

Table 1. Comparison of major cereal production and mutants released in the world.

\begin{tabular}{ccc}
\hline Crop & Production (m tones) (2011) & Mutants released (1955-2011) \\
\hline Maize & 886 & 96 \\
Rice & 726 & 821 \\
Wheat & 698 & 289 \\
Barley & 133 & 309 \\
Sorghum & 57 & 15 \\
Millet & 27 & 5 \\
Oats & 22 & 23 \\
Rye & 13 & 4 \\
\hline
\end{tabular}

Source: [1]. 
Table 2. Sorghum mutants varieties registered in different countries of the world.

\begin{tabular}{|c|c|c|c|c|}
\hline Variety Name & Country (Year) & Character Improvement Details & Mutant Development Type & Type of Mutagen \\
\hline PAHAT & Indonesia (2011) & $\begin{array}{l}\text { High yielding, semi dwarfness, early maturity, } \\
\text { grain quality (protein, tannin, starch) }\end{array}$ & Direct use of an induced mutant & Gamma rays \\
\hline Yuantian No.1 & China (2002) & $\begin{array}{l}\text { More sugar content }(20 \%) \text {, excellent source both } \\
\text { as a feed and as a bio-energy crop, or a } \\
\text { bio-ethanol producer, grown on approximately } \\
1,000 \text { ha }\end{array}$ & Direct use of an induced mutant & Gamma rays \\
\hline Yuanza 502 & China (2002) & High yield (20\%) & Crossing with one mutant & Space breeding \\
\hline Fambe & Mali (1998) & $\begin{array}{l}\text { Resistance to lodging and high grain yield } \\
\text { (increased number of grains per panicle) }\end{array}$ & Direct use of an induced mutant & Gamma rays (300 Gy) \\
\hline Sofin & Mali (1998) & $\begin{array}{l}\text { Early maturity, dwarfness and resistance to } \\
\text { lodging }\end{array}$ & Direct use of an induced mutant & Gamma rays (250 Gy) \\
\hline Tiedjan & Mali (1998) & $\begin{array}{l}\text { Longer panicle size, larger grain size and late } \\
\text { maturity }\end{array}$ & Direct use of an induced mutant & Gamma rays (100 Gy) \\
\hline Djeman & Mali (1998) & $\begin{array}{l}\text { White color of the grains, high grain yield and } \\
\text { late maturity }\end{array}$ & Direct use of an induced mutant & Gamma rays (100 Gy) \\
\hline Djemanin & Mali (1998) & $\begin{array}{l}\text { White grain color, high grain yield and longer } \\
\text { panicle length }\end{array}$ & Direct use of an induced mutant & Gamma rays (100 Gy) \\
\hline Gnoumanin & Mali (1998) & $\begin{array}{l}\text { Yellow color of the grains, high grain yield and } \\
\text { longer panicle length }\end{array}$ & Direct use of an induced mutant & Gamma rays (100 Gy) \\
\hline Gnome & Mali (1998) & Resistance to lodging and high grain yield & Direct use of an induced mutant & Gamma rays (300 Gy) \\
\hline Sadje & Mali (1998) & Early maturity and shortness & Direct use of an induced mutant & Gamma rays (300 Gy) \\
\hline Longfuliang 1 & China (1978) & $\begin{array}{l}\text { Early maturity, short straw and suitable for } \\
\text { close planting }\end{array}$ & Direct use of an induced mutant & Gamma rays (200 Gy) \\
\hline Co 21 & India (1977) & $\begin{array}{l}\text { Tall and high yielding grain and fodder type, } \\
\text { sweet stem, tolerant to major insects and } \\
\text { pathogens }\end{array}$ & Direct use of an induced mutant & Gamma rays (400 Gy) \\
\hline Jinza 1 & China (1970) & $\begin{array}{l}\text { Improved quality, higher yield and wide } \\
\text { adaptability }\end{array}$ & Crossing with one mutant variety & Gamma rays \\
\hline Jinfu 1 & China (1970) & Better quality for machine harvest & Direct use of an induced mutant & Gamma rays (240 Gy) \\
\hline
\end{tabular}

Source: [16].

and tolerance to stresses such as drought and soil acidity [14]. Three improved varieties of drought tolerant, semi-dwarf stature, early maturity and high yielding (over 4 tons/ha) were released. The varieties were adapted by both farmers and private companies, grown for grain for developing many kinds of food products while the plant stover is used as animal feed. Additionally, promising mutant lines of drought tolerance have been developed for food, animal feed, and starch and ethanol industry.

According to [38] eight mutant lines were developed through gamma irradiation at the Institute of Agronomic Research (IAR), Samaru, Zairia, Nigeria. These mutants were selected based on early and synchronous maturity, reduction in plant height, higher yield and large grain size. Some mutant lines were found to be useful directly as varieties and other lines were good combiners as they had high general combining ability (GCA). As revealed by [39] the agro- 
nomic traits of locally adapted sorghum in Mali were changed by gamma irradiation. This includes changes in plant height, lodging tolerance, drought tolerance, panicle length and compactness, seed size and color, seed quality and protein content, maturity, and tillering ability. A breeding program at Research Farm of the Plant Stress and Germplasm Development Research Unit, USA induced mutation through ethyl methane sulfonate (EMS) generated a nuclear male sterility (NMS) line ( $m s 8)$ [36]. Mutant $m s 8$ has white hairy stigma which emerges first and only small white anthers appears and did not produce pollen grains, making it easily recognizable at flowering stage.

In another study the chemical agent ethyl methane sulfonate (EMS) was used to generate 1600 mutant lines from an elite variety [40]. Their study developed two mutant lines of brown midrib (bmr) phenotype, a trait associated with low lignin content and increased digestibility. A breeding program by [41] confirms creating six sorghum bloomless (bm), a trait known to increase resistance to greenbug and sheath blight. This study confirms the utilization of marker-assisted selection to fast track the selection process. Thus induced mutations might be useful tool in generating the diversity genetic which may supplement conventional breeding methods to desired crop varieties.

\section{Future Implication of Sorghum Mutation Breeding in Namibia}

\subsection{Sorghum Production in Namibia and the World}

Sorghum production in Namibia and the rest of the world is summarized in Table 3 [1]. The figures show that in 2016 Africa contributed 46.7\% (29.8 tons) of sorghum produced worldwide (63.9 tons). Sudan had the largest area $(9.2 \mathrm{~m} \mathrm{ha})$ under sorghum production followed by Nigeria ( $5.8 \mathrm{~m} \mathrm{ha}$ ) and India $(5.7 \mathrm{~m} \mathrm{ha})$. The USA was the greatest producer ( $12.2 \mathrm{~m}$ tons) followed by Nigeria $(6.94 \mathrm{~m}$ tons) and Sudan (6.47 $\mathrm{m}$ tons). In comparison with sorghum production elsewhere in the world, Namibia had the lowest production in terms of the area $(22,004 \mathrm{ha})$, production quantity (6287 tons) and productivity (286 kg/ha) [1]. In the past two decades there was a decline in area under sorghum $(-1.1 \%)$, production quantity $(-1.4 \%)$ and productivity $(-0.32 \%)$ in Namibia. The decrease in sorghum productivity over a period of two decades in Namibia remains a concern that needs interventions to stimulate its production.

\subsection{Factors for Declining Area under Sorghum}

Numerous issues have attributed to the declined area under sorghum in the past two decades in Namibia. Firstly, there is lack of market for sorghum grain as compared with maize, pearl millet and wheat, also known as controlled crops [42]. Secondly, although there are government subsidies on dry-land cultivation, there are limited policies on output price incentives which are provided for maize and pearl millet [3] [42] [43]. Thirdly, there is undocumented perception of low consumer preference of sorghum over pearl millet and maize. Fourthly, 
Table 3. Comparison of Namibia sorghum production with the rest of the world.

\begin{tabular}{|c|c|c|c|c|c|c|c|c|c|}
\hline \multirow{2}{*}{ Country } & \multicolumn{3}{|c|}{ Area (m ha) } & \multicolumn{3}{|c|}{ Production ( $\mathrm{m}$ tons) } & \multicolumn{3}{|c|}{ Productivity (kg/ha) } \\
\hline & Av & 2016 & $\% \#$ & $\mathrm{Av}$ & 2016 & $\%$ \# & $\mathrm{Av}$ & 2016 & $\% \#$ \\
\hline World & 43.18 & 44.77 & 3.7 & 60.74 & 63.93 & 5.3 & 1407 & 1428 & 1.52 \\
\hline Africa & 25.30 & 30.55 & 20.7 & 23.20 & 29.83 & 28.6 & 917 & 977 & 6.52 \\
\hline Sudan & 6.78 & 9.16 & 35.0 & 4.45 & 6.47 & 45.2 & 656 & 706 & 7.56 \\
\hline Nigeria & 6.31 & 5.82 & -7.9 & 7.42 & 6.94 & -6.5 & 1175 & 1193 & 1.51 \\
\hline India & 8.41 & 5.65 & -32.8 & 7.09 & 4.41 & -37.8 & 843 & 781 & -7.44 \\
\hline Niger & 2.70 & 3.60 & 33.5 & 0.92 & 1.81 & 96.8 & 340 & 502 & 47.38 \\
\hline USA & 2.81 & 2.49 & -11.4 & 11.47 & 12.20 & 6.3 & 4078 & 4891 & 19.93 \\
\hline Ethiopia & 1.48 & 1.88 & 27.2 & 2.62 & 4.75 & 81.1 & 1774 & 2525 & 42.34 \\
\hline Namibia & 0.02 & 0.02 & -1.1 & 0.001 & 0.001 & -1.4 & 287 & 286 & -0.32 \\
\hline
\end{tabular}

Av: average 1996-2016, \#: Change in 2016 over Av; Source: [1].

although mixed farming of crops and animal is common in Namibia, sorghum is not popular for feed and fodder [44]. Therefore, comprehensive studies and policies are needed to effectively revive sorghum production and promote it as a food and profitable crop for the driest country in sub-Saharan Africa (Table 4).

The productivity of grain sorghum in Namibia is less than $300 \mathrm{~kg} / \mathrm{ha}$ [1]. The poor yields are a result of biotic and abiotic stresses besides non-adoption of improved cultivars and management practices [45]. Prominent abiotic stresses are poor soil fertility and drought while important biotic stresses are bird damage, stem borer, grain mold, head bugs, leaf blight, sooty stripe, striga, anthracnose and storage pest [9] [11]. The most important intervention to improve yields is to adopt appropriate agronomic practices of improved soil and crop management along with improved variety [46]. The adoption of seed-based technologies which is based on improved varieties is the lowest cost compared with other agronomic management practices that need to be integrated with other good agricultural practices. Therefore, genetic improvement through tools such as recombination breeding and induced mutation breeding to develop varieties resistant to biotic and abiotic stresses should be given a high thrust in the Namibia.

\section{Conclusion}

In the face of climate change, induced mutation breeding has a significant role to play in the improvement of sorghum production in semi-arid countries like Namibia. The major challenge of sorghum production in Namibia is the competition with other crops such as maize and pearl millet. Given the aridity of Namibia in terms of amount of rainfall received per cropping season, and inter and intra-seasonal rainfall distribution, planting sorghum is less risky than maize. Moreover, induced mutation could play a role in developing biofortified varieties of sorghum of high nutrition food rich in iron and zinc and other essential 
Table 4. Comparison of sorghum production with other cereal crops in Namibia.

\begin{tabular}{cccccccccc}
\hline \multirow{2}{*}{ Country } & \multicolumn{3}{c}{ Area (ha) } & \multicolumn{3}{c}{ Production (tons) } & \multicolumn{3}{c}{ Productivity (kg/ha) } \\
\cline { 2 - 10 } & 1996 & 2016 & $\% \#$ & 1996 & 2016 & $\% \#$ & 1996 & 2016 & $\%$ \# \\
\hline Maize & 27,827 & 30,943 & 11.20 & 19,020 & 63,713 & 2.35 & 684 & 2059 & 201.25 \\
Pearl millet & 260,100 & 228,433 & -12.17 & 56,600 & 44,578 & -0.21 & 218 & 195 & -10.32 \\
Sorghum & 36,800 & 22,004 & -40.21 & 8000 & 6287 & -0.21 & 217 & 286 & 31.43 \\
Wheat & 1300 & 2201 & 69.31 & 5700 & 13924 & 1.44 & 4385 & 6326 & 44.28 \\
\hline
\end{tabular}

\#: Change in 2016 over 1966; Source: [1].

nutrients; hence it can contribute to the reduction of hidden hunger. Therefore, the first step is to establish a well-organized sorghum breeding program and coupled with seed distribution enhance increased sorghum production in farmers' fields and regulate sorghum-value-chain for the benefit of producers and consumers without compromising food security. The market driven demanded traits should be coupled with breeding programs, agrochemicals, crop production, farm machinery and value addition. Therefore, there is a need for coordinated approach by stakeholders involved such as the government, non-governmental organization (NGO's), research institutes, farmers and private companies to contribute to the sustainable strategy guidance to sorghum breeding activities. In order to shorten the cycle of sorghum breeding in Namibia, enhancement of genomics and marker-assisted selection and other biotechnology techniques need to be integrated with mutation breeding. This will enable the development and deployment of high yielding, early maturing, and quality, biotic and abiotic stresses tolerant sorghum varieties. High yielding drought tolerant mutants permit increased planting density resulting in higher grain and fodder yields.

\section{Acknowledgements}

The authors thank the Joint FAO/IAEA Programme Nuclear Techniques in Food and Agriculture for supporting induced mutation breeding in Namibia and for providing fellowship training to Mr. Wanga. This work was supported by the Ministry of Agriculture, Water and Forestry of the Republic of Namibia.

\section{Conflicts of Interest}

The authors declare no conflicts of interest regarding the publication of this paper.

\section{References}

[1] FAOSTAT (2018) Area Harvested, Yield and Production Quantity, Sorghum. http://www.fao.org/faostat/en/\#data/QC

[2] AGRIBUSDEV (2017) Agricultural Business Development Agency Annual Report. http://www.agribusdev.org.na/images/Docs/Annual_reports/Agribusev_Annual_Re port_Final_2017.pdf

[3] Namibia Statistics Agency (2015) Namibia Agriculture Communal Sector Census 
2013/14 Report. https://cms.my.na/assets/documents/NAC_2013.pdf

[4] ICRISAT (2018) Sorghum. http://exploreit.icrisat.org/profile/Sorghum/193

[5] Assefa, Y., Staggenborg, S.A., Vara, P. and Prasad, V. (2010) Grain Sorghum Water Requirement and Responses to Drought Stress: A Review. Online Crop Management.

[6] Reddy, B.V.S., Ramesh, S., Ashok, K.A. and Gowda, C.L.L. (2008) Sorghum Improvement in the New Millennium. International Crops Research Institute for the Semi-Arid Tropics, Patancheru.

[7] Schittenhelm, S. and Schroetter, S. (2014) Comparison of Drought Tolerance of Maize, Sweet Sorghum and Sorghum-Sudangrass Hybrids. Journal of Agronomy and Crop Science, 200, 46-53. https://doi.org/10.1111/jac.12039

[8] J. Irish (2018) Sorghum bicolor (L.) Moench in Namibia.

[9] Orr, A., Mwema, C., Gierend, A. and Nedumaran, S. (2016) Sorghum and Millets in Eastern and Southern Africa. Facts, Trends and Outlook. Working Paper Series No. 62, ICRISAT Research Program, Markets, Institutions and Policies, International Crops Research Institute for the Semi-Arid Tropics, Telangana.

[10] MAWF (2015) Namibia Agriculture Policy. Ministry of Agriculture, Water and Forestry (MAWF), Windhoek.

[11] Bantilan, M.C.S., Deb, U.K., Gowda, C.L.L., Reddy, B.V.S., Obilana, A.B. and Evenson, R.E. (2004) Sorghum Genetic Enhancement: Research Process, Dissemination and Impacts. International Crops Research Institute for the Semi-Arid Tropics, Patancheru.

[12] Saadan, H.M., Mgonja, M.A. and Obilana, A.B. (2000) Performance of the Sorghum Variety Macia in Multiple Environments in Tanzania.

https://core.ac.uk/download/pdf/12103854.pdf

[13] Kolberg, H. (1999) Variability in Namibian sorghum (Sorghum bicolor (L.) Moench subsp. bicolor). AGICOLA, Ministry of Agriculture, Water and Forestry, Windhoek.

[14] FAO/IAEA (2017) Plant Mutation Breeding Enhances Crop Productivity and Food Security in Drought-Prone Environment in Namibia.

http://www-naweb.iaea.org/nafa/news/2016-plant-mutation-breeding-namibia.html

[15] FAO/IAEA (2018) Seeds of Hope: Using Mutation Breeding to Strengthen Crops in Namibia. https://www.iaea.org/sites/default/files/18/09/nam5014_success_story_2018.pdf

[16] FAO/IAEA (2018) Mutant Variety Search. International Atomic Energy Agency (IAEA). https://mvd.iaea.org/\#!Search

[17] De Wet, J.M.J. and Huckabay, J.P. (1967) The Origin of Sorghum Bicolor. II. Distribution and Domestication. Evolution, 21, 787-802. https://doi.org/10.1111/j.1558-5646.1967.tb03434.x

[18] Winchell, F., Stevens, C.J., Murphy, C., Champion, L. and Fuller, D.Q. (2017) Evidence for Sorghum Domestication in Fourth Millennium BC Eastern Sudan: Spikelet Morphology from Ceramic Impressions of the Butana Group. Current Anthropology, 58, 673-683. https://doi.org/10.1086/693898

[19] Novak, F.J. and Brunner, H. (1992) Plant Breeding: Induced Mutation Technology for Crop Improvement. IAEA Bulletin, 4, 25-33.

[20] Shu, Q.Y., Forster, B.P. and Nakagawa, H. (2011) Plant Mutation Breeding and Biotechnology. Plant Breeding and Genetics Section, Joint FAO/IAEA Division of Nuclear Techniques in Food and Agriculture, International Atomic Energy Agency, 
Vienna.

[21] Oladosu, Y., Rafii, M.Y., Abdullah, N., Hussin, G., Ramli, A., Rahim, H.A., Miah, G. and Usman, M. (2016) Principle and Application of Plant Mutagenesis in Crop Improvement: A Review. Biotechnology \& Biotechnological Equipment, 30, 1-16. https://doi.org/10.1080/13102818.2015.1087333

[22] House, L.R. (1985) A Guide to Sorghum Breeding. 2nd Edition, International Crops Research Institute for the Semi-Arid Tropics, Patancheru.

[23] Acquaah, G. (2012) Principles of Plant Genetics and Breeding. 2nd Edition, Wiley-Blackwell, John Wiley \& Sons, Chichester. https://doi.org/10.1002/9781118313718

[24] Lasky, J.R., Upadhyaya, H.D., Ramu, P., Deshpande, S., Hash, C.T., Bonnette, J., Juenger, T.E., Hyma, K., Acharya, C., Mitchell, S.E., Buckler, E.S., Brenton, Z., Kresovich, S. and Morris, G.P. (2015) Genome-Environment Associations in Sorghum Landraces Predict Adaptive Traits. Science Advances, 1, e1400218.

[25] Morris, G.P., Ramu, P., Deshpande, S.P., Hash, C.T., Shah, T., Upadhyaya, H.D., Riera-Lizarazu, O., Brown, P.J., Acharya, C.B., Mitchell, S.E., Harriman, J., Glaubitz, J.C., Buckler, E.S. and Kresovich, S. (2013) Population Genomic and Genome-Wide Association Studies of Agroclimatic Traits in Sorghum. PNAS, 110, 453-458.

[26] Cheema, A.K. (2018) Plant Breeding Its Applications and Future Prospects. International Journal of Engineering Technology Science and Research, 5.

[27] FAO/IAEA (2018) Manual on Mutation Breeding. 3rd Edition, Food and Agriculture Organization of the United Nation, Rome, $301 \mathrm{p}$.

[28] Human, S., Sihono, S. and Parno, P. (2006) Application of Mutation Techniques in Sorghum Breeding for Improved Drought Tolerance.

[29] Xin, Z., Wang, M.L., Burow, G. and Burke, J.J. (2009) An Induced Sorghum Mutant Population Suitable for Bioenergy Research. BioEnergy Research, 2, 10-16. https://doi.org/10.1007/s12155-008-9029-3

[30] Deshmukh, S.B., Bagade, A.B. and Choudhari, A.K. (2018) Induced Mutagenesis in Rabi Sorghum. International Journal of Current Microbiology and Applied Sciences, 6, 766-771.

[31] Mani, N.S. (1989) EMS-Induced Mutagenesis in Sorghum bicolor (L.) Moench. Proceedings of the Indian National Science Academy, 477-482.

[32] Yadav, P., Meena, H. S., Meena, P. D., Kumar, A., Gupta, R., Jambhulkar, S., Rani, R. and Singh, D. (2016) Determination of LD50 of Ethyl Methanesulfonate (EMS) for Induction of Mutations in Rapeseed-Mustard. Journal of Oilseed Brassica, 7, 77-82.

[33] Bretaudeau, A. (1997) Radiation Induced Mutations for Breeding of Sorghum. Proceedings of a Final Research Co-Ordination Meeting, Joint FAO/IAEA Division of Nuclear Techniques in Food and Agriculture, Vienna, 145, 25-29.

[34] Sreeramulu, K. (1971) Effectiveness and Efficiency of Single and Combined Treatments of Radiations and Ethyl Methane Sulphonate in Sorghum. Proceedings of the Indian Academy of Sciences, Section B, 74, 147.

[35] Hanna, W.W. (1982) Mutation Breeding of Pearl Millet and Sorghum, Joint FAO/IAEA Division of Isotope and Radiation Applications, of Atomic Energy for Food and Agricultural Development International Atomic Energy Agency, Vienna.

[36] Suthakar, V., Mullainathan, L. and Elangovan, M. (2014) Mutagenic Effect of Gamma Rays and EMS on Yield Attributes of Sorghum (Sorghum bicolor (L.) Moench) in M1 Generation. International Journal of Advanced Research, 2, 
453-455

[37] Xin, Z., Huang, J., Smith, A.R., Chen, J., Burke, J., Sattler, S.E. and Zhao, D. (2017) Morphological Characterization of a New and Easily Recognizable Nuclear Male Sterile Mutant of Sorghum (Sorghum bicolor). PLoS ONE, 12, e0165195. https://doi.org/10.1371/journal.pone.0165195

[38] National Research Council (1996) Lost Crops of Africa: Volume I. Grains. The National Academies Press, Washington DC.

[39] Kenga, R., Alabi, S.O. and Gupta, S.C. (2005) Heterosis and Combining Ability for Grain Yield and Its Components in Induced Sorghum Mutations. African Crop Science Journal, 13, 143-152.

[40] Mba, C., Afza, R., Bado, S. and Jain, S.M. (2010) Induced Mutagenesis in Plants Using Physical and Chemical Agents. In: Davey, M.R. and Anthony, P., Eds., Plant Cell Culture: Essential Methods, John Wiley \& Sons, Ltd., Chichester, 111-130.

[41] Xin, Z., Wang, M.L., Barkley, N.A., Burow, G., Franks, C., Pederson, G. and Burke, J. (2008) Applying Genotyping (TILLING) and Phenotyping Analyses to Elucidate Gene Function in a Chemically Induced Sorghum Mutant Population. BMC Plant Biology, 8, 103. https://doi.org/10.1186/1471-2229-8-103

[42] Mizuno, H., Kawahigashi, H., Ogata, J., Minami, H., Kanamori, H., Nakagawa, H. and Matsumoto, T. (2013) Genomic Inversion Caused by Gamma Irradiation Contributes to Downregulation of a WBC11 Homolog in Bloomless Sorghum. Theoretical and Applied Genetics, 126, 1513-1520. https://doi.org/10.1007/s00122-013-2069-x

[43] Namibian Agronomic Board (2017) Annual Report 2016-2017. Namibian Agronomic Board, Windhoek Namibia.

[44] MAWF (2015) Comprehensive Conservation Agriculture Programme for Namibia 2015-2019. Ministry of Agriculture, Water and Forestry (MAWF), Windhoek Namibia.

[45] Mendelsohn, J., El Obeid, S., De Klerk, N. and Vigne, P. (2006) Farming Systems in Namibia. RAISON (Research \& Information Services of Namibia), Windhoek, Namibia.

[46] Iijima, M., Awala, S.K., Nanhapo, P.I., Wanga, A. and Mwandemele, O.D. (2018) Development of Flood- and Drought-Adaptive Cropping Systems in Namibia. In: Kokubun, M. and Asanuma, S., Eds., Crop Production under Stressful Conditions, Springer, Singapore, 49-70. https://doi.org/10.1007/978-981-10-7308-3_4 